\title{
Financing lifelong learning
}

\author{
Hessel Oosterbeek ${ }^{a}$, Harry Anthony Patrinos ${ }^{b, *}$ \\ ${ }^{a}$ Universiteit van Amsterdam School of Economics \\ ${ }^{b}$ World Bank
}

\begin{abstract}
This paper describes and analyzes different financial schemes to promote lifelong learning. Positive effects of financial incentives to pupils are not restricted to high ability pupils, as low ability students also seem to benefit. The evidence regarding the effects of subsidy forms is limited. The most prominent knowledge gaps regarding the effects of various financing schemes related to lifelong learning are the effects of vouchers; financial aid schemes for students; and entitlements and individual learning accounts.
\end{abstract}

Keywords: lifelong learning, finance, training

\section{Introduction}

Different financial schemes to promote lifelong learning have been put forward (World Bank, 2003). There is a belief that current expenditures are directed to learners and providers in an inefficient way. By giving better incentives more can potentially be achieved with the same amount of resources. There is the notion that spending on education needs to be increased to meet the requirements of the knowledge economy, and that this should be achieved by increasing private expenditures on education, both directly and by creating new sources of finance.

Considered in this review are financial instruments to stimulate lifelong learning. We apply the standard normative framework of welfare economics and discuss relevant empirical findings. The education finance literature has traditionally paid much attention to financial aid schemes for higher education. A standard economic analysis of capital market failures provides reasons for government intervention. Despite the almost universal enthusiasm about income contingent loans among economists, practical experience with such schemes is very limited.

To stimulate lifelong learning, it is often believed that simply making such activities available below marginal costs provides insufficient incentives. Instruments such as vouchers, entitlements and individual learning accounts give potential learners a very explicit confirmation of their increased purchasing power. This should strengthen people's awareness of the importance of learning activities. The evidence of the effects of these subsidies is limited.

\footnotetext{
*Corresponding author: hpatrinos@worldbank.org. The views expressed here are those of the authors and should not be attributed to the authors' organizations. We thank Stefan Wolter for useful comments.
} 
The importance of investments in education is widely documented in terms of earnings and employment. For individuals, education also has other important benefits, such as health (Grossman, 2006). Also, investment in education is regarded as an engine for countries' prosperity.

Our analysis of financial schemes fits into the normative economics framework in which efficiency and equity serve as guidelines. We outline an analytical framework that serves as a reference point. We also pay attention to empirical studies that inform us about the effectiveness of various financial arrangements. In reviews of financial arrangements in the field of education, the empirical analysis confines itself often to a description of alleged success stories. We will move away from that custom and instead focus on empirical results coming from studies that use credible strategies to identify the causal impact. By emphasizing this, we will also show that much is still unknown. We apply our analytical framework to various financial arrangements, including various loans schemes, human capital contracts and financial incentives for students. Finally, we bring together insights regarding subsidization mechanisms such as scholarships and grants, vouchers and tax deductions.

\section{Analytical Framework}

According to standard economics, education (formal schooling and training) can be classified as a private good. A good is private rather than public when people can be excluded and when there is rivalry in consumption. Exclusiveness means that it is, at relatively low cost, possible to prohibit a person from using the good. In the case of education, this can be achieved by not allowing someone to enter the school building, the classroom, or the workplace. Rivalry means that the use of the good by one person reduces the opportunities for other persons to use the same good. Again, in the case of education, this condition is satisfied since the attention that a teacher or instructor gives to one student or trainee reduces the amount of time available to others.

Private goods can in principle be provided through the market. Without any form of cooperative action (for example, government intervention) a certain positive quantity of the good is provided. This is not true for pure public goods. If it is impossible to exclude a person from the use of a good and if there is no rivalry in consumption, then provision without some form of cooperation or coordination will be impossible. No single individual will pay for all of the costs, except in the rare case that their private benefits exceed the full costs.

While private provision of education is possible, in almost every country there is some level of government intervention. Intervention takes the form of regulation and/or financing. The amount and form of government intervention in the schooling market differs considerably from country to country. Motives for intervening in the market for education relate to efficiency and equity. The form of intervention is, therefore, typically evaluated in terms of its effects on these criteria. 


\subsection{Efficiency}

Efficiency requires that (social) marginal costs equals (social) marginal benefits. Two main factors are often mentioned as potential sources for inefficiency in education markets: externalities and capital market failures. Here we analyze these factors in some depth. This is important because understanding the precise causes of inefficiencies is helpful in judging the possible effectiveness of suggested solutions. Externalities occur when the production or consumption of a good has effects on people other than the decision-makers. Externalities can be either positive or negative. Since decision-makers are assumed to take only their own private costs and benefits into account, there will be, from a social point of view, an under-provision of goods that generate positive externalities and an overprovision of goods that cause negative externalities. In the case of schooling, the common view is that it produces positive external effects. Attempts have been made to quantify the external effects of schooling by estimating social and private returns separately, but findings diverge considerably. Acemoglu and Angrist (2000) find that almost all of the returns to education are private, while Moretti's (2004) findings imply that the macro impact of education is close to four times the private rate of return. Lange and Topel (2006) conclude that there is no evidence that social returns are smaller than private ones, yet neither is there much to suggest that they are larger.

Aspects that qualify as positive externalities of schooling include: quality of children, health, social cohesion, technological development, income distribution, higher economic growth, less crime, more democracy, philanthropy and political participation (Haveman and Wolfe, 1984). The common view is that externalities of schooling tend to diminish with the level of schooling. If that is the case, the externalities argument cannot explain why in many countries the public subsidy to higher education exceeds that to elementary education. In addition, there is a large body of empirical literature demonstrating that the private returns to education are high enough to pay for its costs (Ashenfelter et al., 1999).

Another form of externality is exclusively connected to investment in firm-specific training. Firm-specific training is defined as training that is only useful in the current firm; it has no value in other firms. By contrast, the definition of general training is that it enhances worker's productivity not only in the current firm but also to the same extent in all firms. Investments in specific training are predicted to be below their efficient level due to holdup. Since the return to specific investments depends on the two parties staying together, one party can always try to get some of the return to the other party's investment by threatening to end the relationship. The investing party will anticipate such opportunistic behavior and will invest below the optimum level. Holdup can only occur when the investment is non-contractible but verifiable. This is likely to be the case for training. Acemoglu and Pischke (1999) have shown that training that is general in a technical sense can still be specific in an economic sense in situations with labor market frictions. This insight enhances the potential relevance of the holdup problem. 
Unless they come from wealthy families, students will typically not have the funds to finance their tuition fees and the cost of living while studying. They will, therefore, have to borrow. Because human capital is stored in persons and is not readily transferable, there is no collateral in case of default. Therefore, private banks will be unwilling to provide student loans without any compensation for the default risk.

More fundamentally, capital market failures can be attributed to adverse selection and moral hazard. Adverse selection refers to the mechanism that a default premium will prevent the lowest risk students from taking up a loan. As a result, the average risk for the remaining cases will be higher and the default premium needs to increase. Moral hazard refers to the fact that after graduation people may be inclined to take no job or a low paying job in order to avoid/evade repayment of the loan.

On average, investments in schooling are beneficial, but earnings prospects are uncertain. Even students with an accurate idea of their own capabilities cannot be certain of their future earnings level. Risk-averse individuals attach heavier weights to bad outcomes than to good outcomes, and may, therefore, underinvest in education.

A concept that only recently attracted the attention of economists, and which is relevant from the perspective of education investments, is debt aversion. This refers to the fact that people dislike carrying debt over and above the consequences of debt on consumption patterns.

\subsection{Equity}

Probably the most important reason for intervening in education markets is the widely supported view that participation in learning activities should depend only on characteristics that are relevant to education, such as motivation, effort and ability, and not on other factors such as social background, gender or race. Much effort is put into realizing equal opportunities.

With regard to equity, it is important to distinguish between static and dynamic measures. In the static case, it is only current income positions that matter, whereas in the dynamic case it is the lifetime perspective. Put differently, with the static equity concept, it matters that students with poorer social backgrounds have equal access to post-compulsory schooling. Whereas from a dynamic point of view, it matters that those who have attained the highest levels of schooling are among the richest of their cohort. Thus, for the evaluation of subsidies to students, it matters not only whether these students come from poor families, but also whether the subsidies take the lifetime position of the recipients into account.

Related to equity is the fact that individuals may underestimate the value that schooling has for them. If a government thinks it knows better what is good for a person than the person himself, then this is a case of paternalism. The general belief is that paternalism plays a role in education at the elementary and secondary level, but not at the post-secondary level. The reason for this is that there is a contradiction 
in thinking that people who are qualified to enroll in post-secondary schooling are so ignorant that they do not know what value education has for them. The notion of dynamic spillovers reinforces the case for paternalism. This is especially a concern for children with less-educated parents.

\subsection{Evidence-Based Policies}

Financial arrangements are a form of policy intervention. In recent years, the evaluation of policy interventions has gained much attention in scholarly papers. To identify the impact of an intervention one has to know what would have happened to persons who were exposed to the intervention in its absence. The construction of a credible counterfactual is a difficult task. Just comparing outcomes of those who were treated by the intervention with the outcomes of those who were not treated is likely to be misleading. The reason is that in most cases treatment is not provided randomly, but is based on (self-) selection.

An experimental setup with randomized assignment to treatment and control groups is regarded by many as the gold standard to estimate the impact of an intervention. While this is probably true in many relevant applications, it is important to realize that even such a setup can give biased results. This is, for instance, the case when there are spillover effects in which outcomes of untreated people are also affected by the policy. An example is that the provision of training for some unemployed persons can reduce the employment prospects of unemployed people who did not receive the training. Another potential problem with the experimental setup is that untreated persons may attempt to obtain substitute treatment. Experimental designs should be set up in a way that such potential problems are addressed.

In addition to the randomized design, other methods operate in the same spirit. In such natural or quasi-experiments, researchers exploit circumstances in which comparable observations are treated differently. In the ideal situation, subjects cannot affect their treatment status. The challenge is to find a source of exogenous variation that affects treatment and has at the same time no direct effect on the outcomes of interest. Attention to evidence-based policies requires consideration about how the counterfactual was constructed. There is only evidence in favor or against policy interventions if it results from research with a carefully constructed control group.

\section{How to Stimulate Lifelong Learning?}

This section presents various forms of funding governments use. Brief descriptions of instruments are provided along with a discussion of how these forms are connected to the reasons for government intervention. Credible research findings regarding the effects of actually implemented funding schemes are analyzed. 


\subsection{Cost-Sharing Schemes}

To address the inefficiency of capital market failure, governments implement or support financial aid schemes in which students can borrow against conditions that are more favorable than what the private market offers. We consider the following financial aid schemes: (1) mortgage-type loans, (2) income contingent loans, (3) graduate tax and (4) human capital contracts. We summarize evidence on the effect of financial incentives on achievement of students in higher education.

Mortgage-type loans. The most popular student finance scheme is traditional mortgage-type loans. This scheme is likely to be offered only to families who have assets to serve as collateral-that is, precisely those who need financial aid the least. In a mortgage-type loans model, students are given loans, which they are required to repay in the form of fixed installments. The interest rate is typically below the rate that private banks would charge.

At first sight, the mortgage loans model seems to address the capital market failure. The exact details of such models may differ. A textbook example of a mortgage model is the current system operating in the Netherlands. In this scheme, the loan only has to be repaid over a particular period if the borrower's income exceeds a certain threshold. Also, in this model there is a rule that fixes the number of years in which the loan has to be repaid to 15 years. If the repayment is not completed within that period, it is remitted. This restricted repayment duration is however at odds with the idea that schooling is an investment in future opportunities. Comparing age-earnings profiles by level of schooling, it is evident that the returns to schooling materialize at later ages. It would be optimal to synchronize repayment and obtaining the returns. A short repayment period is not appropriate.

Traditional student loans have been collected by the state, by private banks, and by universities. Collection has been poor or costly where the taxing power of the state has not been used as a last resort to collect the loans. In some cases, as in the Philippines, poor collection rates have caused such schemes to operate at a loss.

Income contingent loans. During the past decades economists have advocated a system with income contingent loans (Barr, 1993; Chapman, 2006). Students can take up a loan, which they have to repay in the form of a percentage of their earnings after graduation. Compared with the mortgage-type loans, repayment is more evenly spread over graduates' careers. That is, the costs of the investment in schooling are repaid when the returns materialize.

A separate issue relates to the interest rate that students pay. From the point of view of the lender, it is desirable that the interest rate includes a premium for defaulters. This is feasible if an individual's probability of default is as uncertain to the borrower as it is to the lender. That is, however, not very likely; borrowers know more about their own characteristics and, therefore, about their own risk than do lenders. As a result, bad risks will drive good risks out of the market. The relevance of this mechanism increases with the heterogeneity of the student population. Since enrollment in post-secondary education has increased in recent decades, the student 
population has become diverse. The important message is that the government has to be careful when determining the default premium included in the interest rate. Moreover, adverse selection may be a problem. If the lender is unable to shift the risk of default to borrowers, it is reasonable that the lender should screen students for eligibility. Academic records are likely to be a good indicator of the student's future default probability.

The more successful adoptions of income contingent loan schemes took place in Australia, New Zealand, South Africa and the United Kingdom (Chapman, 2006). Two critical aspects of the schemes in these countries relative to others are noted. The first is that these countries all have a taxation system in place that could be used to collect repayments effectively. The second is that in these countries the vast majority of universities are public sector institutions, so that the collection (tax) authority and the education providers operate under the same system and the same terms.

Systems and structures most resembling the successful developed countries are not often available and many developing countries have difficulties associated with the establishment of the policy's integrity, credibility and collection (Chapman, 2006). Given this policy context, it may be desirable that developing countries proceed with the imposition of up-front fees and scholarships instead of income contingent loans.

An important issue concerning the introduction of income contingent loans is to what extent it affects access to higher education, especially for students from poor families. The only country for which this has been documented extensively is Australia. Chapman and Ryan (2002) compare participation rates for 18-year-olds by family wealth before the introduction of the scheme, after the introduction of the scheme, and after some substantial changes have taken place. Over time participation rates for all family wealth categories - including those from the lowest quartile - have increased. This is presented as evidence that the system did not result in decreases in the participation of prospective students from relatively poor families (Chapman, 2006). While factually correct, this statement is somewhat misleading. Introduction of the income contingent loan scheme is Australia was not associated with a reduction in participation of students from poor families when participation rates before and after the introduction are compared. This does not exclude, however, the possibility that participation rates of this group measured after the introduction would have been higher if the system had not been introduced. In other words, Chapman's (2006) statement takes the before participation rates as counterfactual, thereby ignoring changes that would have occurred in the absence of the policy. The positive evaluation of the Australian model would have been much more convincing if based on a randomized experiment or some other design with a proper comparison group.

Graduate tax. In a system with graduate taxes, students receive a public subsidy while studying and repay this in the form of a special tax after graduation. Graduate taxes are often regarded as an imperfect substitute of the ideal system with income contingent loans. Graduate taxes and income contingent loans are similar in many ways, but graduate taxes have the disadvantage that they also provide funding to students who do not want it or need it, and that graduates may end up paying (much) 
more than they received in the form of a grant. This latter feature may provide a disincentive to study to those who would have earned a high income even without the education. The problem is that the graduate tax is levied based on total earnings rather than the earnings increment due to the extra education.

The relative appraisal of graduate taxes changes when prospective students are debt-averse. In that case it makes a difference that under an income contingent scheme students carry debt whereas under a graduate tax scheme they do not carry debt, even though the actual "repayment" of the loan/grant are exactly the same. Theory predicts that debt-averse individuals are more willing to enroll in education when financial aid is in the form of a graduate tax then when given in the form of an income contingent loan.

Graduate taxes are not in operation anywhere, and it is thus impossible to evaluate them. Yet, some insight about their potential can be gained from studies that inform us about the relevance of debt aversion. Two recent empirical studies from selective colleges in the United States provide evidence for the presence of debt aversion.

In a recent study, Field (2006) reports on an experiment in which law students at New York University were randomly assigned to one of two financial aid conditions. The first, standard, condition is a loan repayment assistance program (LRAP) which forgives all graduates who choose careers in the public sector or other low paying fields of law the majority of educational loans incurred during law school through quarterly prospective funding for up to ten years following graduation. The second, innovative, condition consists of public service scholarships (PSS) that provide grants of two-thirds tuition that convert to a loan in the event the recipient does not pursue a public interest law career. The two schemes are identical in terms of financial consequences and differ only in duration of indebtedness. Under the LRAP scheme, people have a debt position from the start. Under the PSS scheme, people only carry a debt burden when they do not pursue a public interest law career. Field's (2006) results show differences in outcomes between the two treatments. In classes for which the lottery was announced prior to enrolment, those in the PSS treatment are twice as likely to enroll. Moreover, those in the PSS treatment are also substantially more likely to have a first job in public interest law. Field (2006) interprets her findings as evidence of debt aversion: behavior is consistent with utility being negatively affected by carrying debt loads.

Data from a highly selective university that introduced a "no-loans" policy under which the loan component of financial aid awards was replaced with grants was recently analyzed (Rothstein and Rouse, 2007). This natural experiment identifies the impact of student debt on employment outcomes. Debt causes graduates to choose substantially higher-salary jobs and reduces the probability that students choose lowpaid "public interest" jobs. There is also some evidence that debt affects students" academic decisions during college. The authors offer two potential explanations for their findings: (1) young workers are credit constrained and (2) they are averse to holding debt. 
Data from a recently collected survey among higher education students in the Netherlands indicate that debt aversion is significantly higher among students whose father has a lower level of education. A regression of debt aversion on level of father's education gives a coefficient of -0.028 , suggesting that especially children from poorer backgrounds may benefit from the introduction of a graduate tax scheme.

Human capital contracts. A human capital contract is a contract in which students agree to pay a percentage of their income for a specified period after graduation in exchange for funds to finance their education. Originally proposed by Milton Friedman (Friedman and Kuznets 1945; Friedman 1955), the idea of such contracts has re-emerged in recent years.

An essential characteristic of human capital contracts is that investors determine the percentage of future income that students have to commit, which could vary depending on the type of learning undertaken and the investor's judgment about the borrower's likely future income. From an efficiency perspective, optimal results are achieved when market forces determine the percentage of income that learners have to commit and externalities are covered by public subsidy. For the outcomes to optimize social welfare, distributional considerations must also be taken into account by targeting public subsidies in order to achieve equity.

Implementation of human capital contracts is constrained by the difficulty of obtaining information on learners, the need for a developed tax collection agency, and the problem of adverse selection (Palacios, 2004). There are now some examples of human capital contracts in practice. MyRichUncle was the first company offering human capital contracts in the United States. The company switched, however, to offer student loans, and more recently stopped lending altogether. CareerConcept in Germany has until now financed hundreds of students and continues growing. Lumni in Chile and Colombia is still very small but continues growing. With this limited scale of operation, and without any attempt to evaluate, little can be said about the effectiveness of this instrument.

Financial incentives for students. A randomized experiment involving two strategies designed to improve outcomes among first-year undergraduates at a large Canadian university was evaluated (Angrist et al., 2006). One group was offered peer advising and organized study group services. Another was offered substantial meritscholarships for solid first year grades. A third group combined both interventions. The authors find that service take-up rates were much higher for students offered both services and scholarships than for those offered services alone. They also find that females used services more than males. No program had an effect on grades for males. First-term grades were significantly higher for females in the two scholarship treatment groups. These effects faded somewhat by year's end, but remain significant for females who planned to take enough courses to qualify for a scholarship. There also appears to have been an effect on retention for females offered both scholarships and services. This effect is large enough to generate an overall increase in retention. The authors conclude that the results suggest that a combination of services and incentives is more promising than either alone, especially for females. 
A randomized experiment where first-year university students could earn financial rewards for passing all first year requirements within one year was conducted (Leuven et al., 2005). They find small and non-significant average effects of financial incentives on the pass rate and the numbers of collected credit points. There is, however, evidence that high ability students collect significantly more credit points when assigned to (higher) reward groups. Low ability students collect less credit points when assigned to higher reward groups. After three years these effects have increased, suggesting dynamic spillovers. The small average effect in the population is, therefore, the sum of a positive effect for high ability students and an (partly) offsetting negative effect for low ability students. A negative effect of financial incentives for less able individuals is in line with research from psychology and recent economic laboratory experiments, which shows that external rewards may be detrimental for intrinsic motivation.

Partly motivated by the negative incentive effect on low-ability students, Leuven et al. (2007) conducted another randomized field experiment in which first year students attending an introductory microeconomics course were invited to participate in a rank-order tournament. Three leagues were created, one with a high prize $(5,000)$, one with a medium prize $(3,000)$ and one with a low prize $(1,000)$. The best performing student in each group wins the prize. Upon application, students were asked to choose for which of the three prizes they wanted to play. The motivation for this is that this could (self-)select students into more homogeneous ability groups such that low-ability students compete with each other. Within each group students were randomly assigned to treatment groups (these could actually win a prize) and control groups (they could not win a prize). The results are somewhat disappointing. Students in treatment groups have the same effort (measured as attendance and preparation time) and achievement (measured as exam score) as students in the control groups. The only exception is that treated students tend to attend the very first meeting after announcement of the results of the randomization more often than control students. This suggests that financial incentives for students (of the size used in this experiment) only have short run effects but no long run effects.

\subsection{Subsidization Mechanisms}

Another category of financial instruments consists of subsidization mechanisms. In this subsection we discuss the following: (1) scholarships and grants, (2) vouchers, entitlements and learning accounts, and (3) tax instruments.

Scholarships/grants. In many countries, tuition fees are heavily subsidized and cover only a small part of the actual costs of education. Motives to do so can be related to the alleged relevance of externalities and may be due to equity considerations. To the extent that equity considerations matter, the subsidies should somehow be related to recipients' social background.

The impact of tuition on enrollment choices has received considerable attention. Kane (2006) provides a brief summary of such studies pertaining to the United 
States. Using different datasets and different identification methods, different studies arrive basically at the same conclusion: an increase in tuition of $\$ 1,000$ translates in a decrease in college enrollment of 4 to 6 percentage points. The lower estimate comes from a study by Dynarski (2003) who exploits the sudden discontinuation of the Social Security Student Benefit program to measure the impact on college attendance. The higher estimate comes from studies that exploit variation in tuition policies across states. Only studies that include state fixed effects tend to report smaller estimates of the effect of a change in tuition on enrollment ( 1 to 2 percentage points per $\$ 1,000)$.

Studies looking at the impact of college costs on enrollment in countries outside the United States tend to find smaller effects. An example is the study by Kodde and Ritzen (1984) for the Netherlands. In a survey they asked prospective students about the earnings expectations with and without further education and about parents' income. They use the estimates on the impacts of these variables to simulate the effect of a change in tuition and find that enrollment is insensitive to such changes. Similar conclusions are drawn from studies that exploit variation in tuition and enrollment over time (Pissarides, 1981, 1982; Canton and De Jong, 2005).

Vouchers. The most elaborated and consistent voucher plan applicable to postcompulsory education was proposed by Levin (1983). As in all voucher models, participants receive the entitlements and the funding follows their choices. Implementation will affect both the supply- and demand-side of the schooling market. On the supply-side, new courses will be offered which are aimed at persons who currently do not enroll in post-compulsory schooling. That such new supply will indeed be offered is shown by experience in the United States with the so-called GI Bill. In a sense, this law constitutes a pilot study with vouchers (O'Neill, 1977). Under the GI Bill, veterans of war are entitled to attend up to 45 months of education during a 10-year period after their active duty. They are entitled to receive an allowance if they attend an accredited schooling or training program. The allowance may be used either to meet the direct schooling costs or to cover costs of living. Many newly established courses have been approved in relation to the GI Bill. Many of these courses were geared towards low-ability veterans, and these courses are believed to have a positive effect on earnings. This contradicts the belief that the voucher mechanism leads to the supply of inferior quality.

Bound and Turner (2002) and Turner and Bound (2003) have looked at the effects of the GI Bill on educational attainment of veterans. Using variation in service during World War II between cohorts, Bound and Turner (2002) estimate significantly positive effects on years of college completed and on the probability of college completion. Turner and Bound (2003) show that this has been accompanied by a widening of the gap in educational outcomes between African-Americans and others.

Messer and Wolter (2009) report on a randomized experiment analyzing the use of vouchers for adult training. The vouchers had a significant impact on participation in training, especially by people who otherwise would not have enrolled in such 
activities. The rate of participation in adult education in the experimental group increased by 20 percent.

Individual Learning Accounts. Individual learning accounts (ILAs) encourage savings for education while providing vouchers to people interested in pursuing training. An ILA is a base amount of resources set aside for an individual to use for his or her learning. ILAs can be used to develop knowledge, skills and abilities that increase their human capital.

An ILA initiative has been running in the Netherlands since 2001. It involves eight pilot projects, each serving up to 150 people. The project includes contributions from learners, employers, and the state. State contributions are budgeted at about $\$ 400$ per learner; employers contribute about $\$ 130-\$ 400$ per learner. The pilots have been confined to particular training fields. Renkema (2006) conducted an in-depth study of the effect of ILAs on recipients' educational intentions. To this end, he focused on two sectors: elderly care and technical installation services. In the first sector he fails to find any effect at all, for the second sector he reports modest positive impacts on intentions; the experimental condition of respondents accounted for only 5 percent of the variation of educational intention, compared to 27 percent for age and 10 percent for prior participation.

Tax instruments. Some countries subsidize training participation through tax instruments. This can be done either by allowing firms to deduct training expenditures from the tax bill, or to allow individuals (workers) to deduct their training expenditures from their income tax. As firms' training expenditures are part of their normal operation costs, firms will normally be allowed to deduct such costs from their tax bill. This is possible in many countries including for instance the Netherlands, Japan, Chile and Canada.

To study the extent to which firms' tax deduction for training expenditures affects training participation, Leuven and Oosterbeek (2004) exploited the feature that the Dutch tax scheme allowed firms to deduct an extra amount in case the training expenditures pertained to the training of workers older than 40 years. This policy created a discontinuity in firms' training costs at the age of 40 . For a worker (just) over 40 years old, training is 14 percent cheaper than for a worker (just) under 40 years old. While the policy was implemented with the aim to stimulate training participation among older workers, the empirical results suggest that this did not happen. Training participation among workers just above 40 is substantially above training participation among workers just below 40. This difference is, however, not the result of increased training rates among older workers but results from decreased training rates among younger workers. Apparently, training participation by workers just below 40 was postponed.

Another possibility is to allow individuals to deduct direct training expenditures from their taxable income. Such tax deduction of training expenditures is possible in various countries including Germany, Italy and the Netherlands (in Italy against the lowest marginal tax rate), but not in other countries such as France, Sweden, Norway and the United Kingdom (where it was recently been replaced by the now 
abandoned individual learning accounts). In some other countries, including the United States, Canada and Australia, training expenditures can be deducted as long as they are made to maintain existing skills. The differences across countries show that tax (non-)deductibility of training expenditures is a policy variable, which is used by some countries, but not by others, as an instrument to stimulate training participation.

The deductibility of direct training expenditures from taxable income was evaluated using two different approaches (Leuven and Oosterbeek, 2007). The main challenge is to isolate the effect of tax deductibility of direct training expenditures from the (implicit) tax deductibility of opportunity costs of training investment and from the taxation of returns to training investments. The first method exploits differences in deductibility rates around kinks in the tax schedule. By choosing the intervals around the kinks such that average net wage rates are equal, they get rid of the tax deductibility of opportunity costs. They also show that future marginal tax rates for individuals who are above and below kinks in a given year are very similar. This eliminates differences in taxation of returns to training. Results based on this approach indicate that a 10 percentage point increase in the tax deductibility rate of direct training expenditures increase training participation by 0.33 percentage points (10 percent increase in training rate).

Their second method takes advantage of the 2001 tax reform, which implied a substantial change in marginal tax rates. Investment costs in 2000 were subject to the old tax code, while investment costs in 2001 were subject to the new tax code. Because returns to training materialize with some delay, returns to investments made in 2000 and 2001 were both subject to the new tax code. Accordingly, this method isolates changes in taxation of costs from changes in taxation of returns. It does not, however, isolate tax deductibility of direct training expenditures from tax deductibility of opportunity costs. This method identifies the joint effect of these two deductibility rates, and since these operate in the same direction, it will overestimate the effect of interest. Results based on this approach indicate that a 10 percentage point increase in the tax deductibility rate of training costs increase training participation by 0.8 percentage points (a 25 percent increase in training rate). The authors show that the ratio of the results from the two methods are informative about the ratio of the opportunity costs of training investments and the direct expenditures of training investments, implying that opportunity costs are 1.5 times as large as direct expenditures.

There is reason to believe the true effect of tax deductibility of direct training expenditures is somewhere in between the estimates from the two methods. To the extent that the first approach does not fully neutralize differences in the taxation of returns, the estimates based on this method underestimate the true effect. Moreover, this method assumes that individuals are fully aware of the marginal tax rate applicable to their training expenditures. If this assumption does not hold for some individuals with incomes close to a kink, these individuals will not act on their tax treatment and their responsiveness will thus be zero. This also biases the estimate 
from the local identification method downwards.

On the other hand, the estimate from the reform method is interpreted as the joint effect of tax deductibility of direct training expenditures and tax deductibility of opportunity costs. The underlying economic model assumes that an individual's opportunity costs of an hour spent on training changes abruptly if this person's taxable income passes a kink in the tax schedule. For people who work full-time (as most people with incomes at least just below the first kink will do) and have little scope to adapt their working hours marginally, this assumption implies that these persons experience an abrupt change in the valuation of their leisure. To the extent that one is unwilling to believe this, a larger share of the effect estimate from the reform approach is attributable to the tax deductibility of direct training expenditures.

The reported effect sizes are evaluated at an average marginal tax rate equal to 0.4. If it is assumed that effects are constant over tax rates the low estimate of 0.3 percentage points change in training participation per 10 percentage point change in deductibility rate, suggests that abolishing the tax deductibility of direct training expenditures reduces the share of individuals who spend money on training for career purposes by almost one half: from 3 percent to 1.7 percent. Using the high estimate of 0.8 percentage points change in training participation per 10 percentage point change in deductibility rate, even suggests that without tax deductibility of direct training expenditures no one would spend money on training for career purposes. In any case, tax deductibility of direct training expenditures appears to be an effective instrument to enhance human capital accumulation. At a marginal tax rate of 0.4 , every Euro invested by the government in the form of a tax deduction, leads to 0.75 to 1.5 euros of private expenditures on training investments.

\section{Summary and Conclusions}

This paper provides a fresh attempt to take stock of the available knowledge and insights regarding schemes to finance lifelong learning. The financial arrangements considered include instruments to stimulate successful learning and incentives for students. We also cover aid schemes such as income contingent loans and graduate taxes and subsidization mechanisms such as vouchers, scholarships and tax rebates.

We applied the standard normative framework of welfare economics that emphasizes the importance of efficiency and equity. In addition, we include discussions of relevant empirical findings where we focus on findings that pass the test of being based on a research design that includes a proper control group. Doing so reveals that much more is known about the effects of some instrument than others. This identifies gaps in our knowledge, summarized in Table 1.

The education finance literature has traditionally paid much attention to financial aid for students. A standard economic analysis of capital market failures provides reasons for government intervention. According to such an analysis the favored form of financial aid is through income contingent loans. Such loans solve the capital marker inefficiency and at the same time confront students with the (marginal) costs 
of their choices. Moreover such loans can also serve equity goals quite well.

Despite the almost universal enthusiasm about income contingent loans among economists, practical experience with such schemes is very limited. Only a few countries have actually implemented such schemes, the best-documented example being Australia. It is often claimed that the introduction of income contingent loan schemes in Australia did not harm the accessibility of higher education for students from low-income families. This claim is probably too optimistic because it is based on comparisons of attendance of these students before and after the introduction of income contingent loans and not on an estimate of what attendance of these students in the period after the introduction would have been in the absence of the income contingent loans.

Another noticeable finding is the recent indications of debt aversion among students at elite universities. Debt aversion refers to disutility of carrying debt over and above the effects of debt on lifetime consumption patterns. If student at elite universities are debt averse, it is very likely that students from poorer social backgrounds are also debt averse. The presence of debt aversion restricts the potential for income contingent loans.

Two Dutch experiments on the role of financial incentives for students show two interesting results. In one experiment students were given incentives in the form of piece rates. While students belonging to the top half of the ability distribution responded to this by collecting more credit points, students belonging to the bottom half of the ability distribution responded by collecting fewer credit points. An explanation for this is that explicit financial incentives have crowded out intrinsic motivation resulting in lower performance. It is useful to know that financial incentives can have such perverse effects. In the other experiment students were given incentives in the form of a tournament. The interesting finding from this study is that students only responded to the incentive in the initial decision making stage.

Lifelong learning activities can be subsidized in various ways. Providing scholarships to those enrolled is heavily used in many education systems. Such subsidies confront students with prices that do not reflect the true marginal costs of their activities. From an efficiency perspective this is only justified if the social marginal returns of their activities exceed the private marginal returns. The mixed evidence on the relevance of externalities casts doubt on the validity of this argument. A vast number of studies indicate that student enrollment in higher education is responsive to changes in prices. A $\$ 1,000$ change in tuition fees changes enrollments rates by 4 to 6 percentage points. Results for other countries suggest that students in these countries are less responsive to price changes. This is probably because tuition levels in these countries are below United States levels.

To stimulate lifelong learning activities of adult workers, it is often believed that simply making such activities available below marginal costs provides insufficient incentives. Instruments such as vouchers, entitlements and individual learning accounts give potential learners a very explicit confirmation of their increased purchasing power. This should strengthen people's awareness of the availability and 
Table 1: Evaluation of Financing Schemes

\begin{tabular}{|c|c|c|c|c|c|}
\hline Scheme & Main motivation & Efficiency effect (in theory) & Equity effect (in theory) & Evidence & Remarks \\
\hline \multicolumn{6}{|l|}{ Cost sharing } \\
\hline $\begin{array}{l}\text { Mortgage type } \\
\text { loans }\end{array}$ & $\begin{array}{l}\text { Lift liquidity } \\
\text { constraint }\end{array}$ & $\begin{array}{l}\text { Addresses capital market } \\
\text { imperfection but imperfectly } \\
\text { since does not align repayment } \\
\text { \& realization of benefits }\end{array}$ & $\begin{array}{l}\text { Likely to be more } \\
\text { attractive for students } \\
\text { from rich backgrounds }\end{array}$ & No evidence available & \\
\hline $\begin{array}{l}\text { Income } \\
\text { contingent } \\
\text { loans }\end{array}$ & $\begin{array}{l}\text { Lift liquidity } \\
\text { constraint }\end{array}$ & $\begin{array}{l}\text { Addresses capital market } \\
\text { imperfection \& aligns } \\
\text { repayment \& realization of } \\
\text { benefits }\end{array}$ & $\begin{array}{l}\text { Equalizing under } \\
\text { traditional assumptions } \\
\text { but not when students } \\
\text { debt-averse }\end{array}$ & $\begin{array}{l}\text { No evidence available on } \\
\text { causal impact of ICL on } \\
\text { access }\end{array}$ & \\
\hline Graduate tax & $\begin{array}{l}\text { Lift liquidity } \\
\text { constraint }\end{array}$ & $\begin{array}{l}\text { Addresses capital market } \\
\text { imperfection, aligns repayment } \\
\& \text { realization of benefits; does } \\
\text { not equalize repaid \& received } \\
\text { amount }\end{array}$ & $\begin{array}{l}\text { Progressive since } \\
\text { graduates earning more } \\
\text { pay more. }\end{array}$ & $\begin{array}{l}\text { No evidence on impacts, } \\
\text { some evidence suggests } \\
\text { debt-aversion important }\end{array}$ & \\
\hline $\begin{array}{l}\text { Human capital } \\
\text { contracts }\end{array}$ & $\begin{array}{l}\text { Lift liquidity } \\
\text { constraint }\end{array}$ & $\begin{array}{l}\text { Market forces determine } \\
\text { payback percentage }\end{array}$ & & $\begin{array}{l}\text { Limited experience, no } \\
\text { evidence }\end{array}$ & \\
\hline $\begin{array}{l}\text { Financial } \\
\text { incentives }\end{array}$ & $\begin{array}{l}\text { Increase effort of } \\
\text { students }\end{array}$ & $\begin{array}{l}\text { Unknown. It can potentially } \\
\text { increase effort to levels above } \\
\text { the optimum }\end{array}$ & $\begin{array}{l}\text { Likely to favor better } \\
\text { students; these students } \\
\text { are more likely to win and } \\
\text { to be more responsive }\end{array}$ & $\begin{array}{l}\text { Evidence from Holland on } \\
\text { piece rates indicate high } \\
\text { ability students benefit, } \\
\text { low ability students } \\
\text { harmed; tournament } \\
\text { effects short lived }\end{array}$ & $\begin{array}{l}\text { Results may be } \\
\text { useful to } \\
\text { include } \\
\text { incentives in } \\
\text { financial aid } \\
\text { schemes }\end{array}$ \\
\hline
\end{tabular}




\begin{tabular}{|c|c|c|c|c|c|}
\hline Scheme & Main motivation & Efficiency effect (in theory) & Equity effect (in theory) & Evidence & Remarks \\
\hline \multicolumn{6}{|l|}{ Subsidization } \\
\hline $\begin{array}{l}\text { Scholarships / } \\
\text { grants }\end{array}$ & $\begin{array}{l}\text { Lift liquidity } \\
\text { constraint }\end{array}$ & $\begin{array}{l}\text { Does not address capital market } \\
\text { imperfection. Possibly } \\
\text { internalizes externalities. } \\
\text { Consumers are not confronted } \\
\text { with true marginal costs. }\end{array}$ & $\begin{array}{l}\text { Depends whether based } \\
\text { on merit or on student } \\
\text { characteristics }\end{array}$ & $\begin{array}{l}\text { U.S. evidence indicates } \\
\text { that } \$ 1000 \text { change in price } \\
\text { changes enrollment by } 4-6 \\
\text { percentage points; results } \\
\text { from other countries } \\
\text { suggest low elasticities }\end{array}$ & \\
\hline $\begin{array}{l}\text { Vouchers / } \\
\text { entitlements / } \\
\text { learning } \\
\text { accounts }\end{array}$ & $\begin{array}{l}\text { Lift liquidity } \\
\text { constraint and } \\
\text { increase market } \\
\text { power of } \\
\text { consumers }\end{array}$ & $\begin{array}{l}\text { Equality of MC and MB; } \\
\text { possible internalization of } \\
\text { externalities }\end{array}$ & $\begin{array}{l}\text { Various possibilities } \\
\text { depending on exact format }\end{array}$ & $\begin{array}{l}\text { Quasi-experimental } \\
\text { evidence shows that GI } \\
\text { Bill increased educational } \\
\text { attainment }\end{array}$ & $\begin{array}{l}\text { But gap in } \\
\text { educational } \\
\text { attainment } \\
\text { between } \\
\text { African- } \\
\text { Americans } \\
\text { and others } \\
\text { increased }\end{array}$ \\
\hline $\begin{array}{l}\text { Tax deductions } \\
\text { for firms }\end{array}$ & $\begin{array}{l}\text { Stimulate } \\
\text { participation } \\
\text { through cost } \\
\text { reduction }\end{array}$ & $\begin{array}{l}\text { Possibly internalizes } \\
\text { externalities }\end{array}$ & Depending on target group & $\begin{array}{l}\text { Dutch evidence shows that } \\
\text { age dependent deduction } \\
\text { let to training } \\
\text { postponement (rather than } \\
\text { increase) }\end{array}$ & \\
\hline $\begin{array}{l}\text { Tax deductions } \\
\text { for workers }\end{array}$ & $\begin{array}{l}\text { Stimulate } \\
\text { participation } \\
\text { through cost } \\
\text { reduction }\end{array}$ & $\begin{array}{l}\text { Possibly internalizes } \\
\text { externalities }\end{array}$ & $\begin{array}{l}\text { Likely to be regressive as } \\
\text { cost reduction increases } \\
\text { with marginal tax rate }\end{array}$ & $\begin{array}{l}\text { Dutch evidence shows } \\
\text { substantial effects }\end{array}$ & \\
\hline
\end{tabular}


importance of learning activities. The available evidence regarding the effects of these subsidy forms is rather limited.

A less explicit way of subsidizing learning activities is in the form of tax deductions. Existing evidence is restricted to one country. An age dependent tax deduction for firms appears to have led to postponement of training activities rather than to an increase. An income tax deduction for individuals appears to have substantially positive effects on training participation.

There remain significant knowledge gaps on the effects of financing lifelong learning. The emphasis in some studies on the advantages of income contingent loan schemes is at odds with the lack of convincing empirical studies. Too little is known about the impacts of vouchers, entitlements and individual learning accounts. It would be worthwhile to undertake well-designed field experiments to study such schemes. It would also be useful if the limited evidence about the impacts of tax deductions were supplemented with other studies.

In recent years some progress has been made. Some programs have been implemented in ways that allow for solid impact evaluations. Much can be gained by following the same strategy for other financial arrangements. The details of such arrangements should be adjusted to local specificities and needs. An experimental setup with randomized assignment to treatment and control groups may be the gold standard. However, other approaches may also be used, some of which may be more appropriate. In natural or quasi-experiments, researchers exploit circumstances in which comparable observations are treated differently. In the ideal situation, subjects cannot affect their treatment status. The challenge is to find a source of exogenous variation that affects treatment and has at the same time no direct effect on outcomes of interest.

\section{References}

Acemoglu, D., \& Angrist J.(2000). How large are the social returns to education? Evidence from compulsory schooling laws. NBER Macroannual, 9-59.

Acemoglu, D., \& Pischke J.-S. (1999). The structure of wage and investment in general training. Journal of Political Economy, 107(3), 539-572.

Angrist, J., Bettinger, E., Bloom, E., King, E., \& Kremer, M. (2002). Vouchers for private schooling in Colombia: Evidence from a randomized natural experiment. American Economic Review, 92(5), 1535-1558.

Angrist, J., Lang, D., \& Oreopoulos, P. (2006). Lead them to water and pay them to drink: An experiment with services and incentives for college achievement. NBER Working Paper No. 12790.

Ashenfelter, O., Harmon, C., \& Oosterbeek, H. (1999). A review of estimates of the schooling/earnings relationship, with tests for publication bias. Labour Economics, 6(4), 453-470.

Barr, N. (1993). Alternative funding resources for higher education. Economic Journal, 103, 718-728.

Bound, J., \& Turner, S. (2002). Going to war and going to college: Did World War II and the G.I. Bill increase educational attainment for returning veterans?. Journal of Labor Economics, 20(4), 784-815.

Canton, E., \& de Jong, F. (2005). The demand for higher education in the Netherlands, 1950-1999. Economics of Education Review, 24, 651-663.

Chapman, B. (2006). Income contingent loans for higher education: international reforms. In E. Hanushek and F. Welch (Eds.) Handbook of the Economics of Education. Amsterdam: North Holland. 
Chapman, B., \& Ryan, C. (2002). Income contingent financing of student higher education charges: Assessing the Australian innovation. Welsh Journal of Education, 11(1), 64-81.

Dynarski, S. (2003). Does aid matter? Measuring the effect of student aid on college attendance and completion. American Economic Review, 93(1), 279-288.

Field, E. (2006). Educational debt burden and career choice: evidence from a financial aid experiment at NYU law school. NBER Working Paper No. 12282.

Friedman, M. (1955). The role of government in public education. In R.A. Solo (Ed.) Economics and the public interest. New Brunswick, NJ: Rutgers University Press.

Friedman, M., \& Kuznets, S. (1945). it Income from independent professional practice. New York: National Bureau of Economic Research.

Grossman, M. (2006). Education and non-market outcomes. In E. Hanushek and F. Welch (Eds.) Handbook of the Economics of Education. Amsterdam: North Holland.

Haveman, R.H., \& Wolfe B.L. (1984). Schooling and economic well-being: The role of nonmarket effects. Journal of Human Resources, 19(3), 377-407.

Kane, T. (2006). Public intervention and post-secondary education. In E. Hanushek \& F. Welch (Eds.) Handbook of the Economics of Education. Amsterdam: North Holland.

Kodde, D., \& Ritzen, J. (1984). Integrating investment and consumption motives in a Neoclassical model of demand for education. Kyklos, 37(4), 598-608.

Lange, F., \& Topel, R. (2006). The social value of education and human capital. In E. Hanushek \& F. Welch (Eds.) Handbook of the Economics of Education. Amsterdam: North Holland.

Leuven, E., \& Oosterbeek, H. (2004). Evaluating the effect of tax deductions on training. Journal of Labor Economics, 22(1), 461-488.

Leuven, E., \& Oosterbeek, H. (2007). The responsiveness of training participation to tax deductibility. Unpublished working paper.

Leuven, E., Oosterbeek, H., \& van der Klaauw, B. (2003). The effect of financial rewards on students' achievement: Evidence from a randomized experiment. CEPR working paper No. 3921.

Leuven, E., Oosterbeek, H., Sonnemans, J., \& van der Klaauw, B. (2007). Rank order tournaments as incentive devices: Evidence from a field experiment. Unpublished working paper.

Levin, H.M. (1983). Individual entitlements. In H.M. Levin \& H.G. Schutze (Eds.) Financing Recurrent Education. Beverly Hills: Sage.

Messer, D., \& Wolter, S.C. (2009). Money matters: Evidence from a large-scale randomized field experiment with vouchers for adult training. CESifo Discussion Paper.

Moretti, E. (2004). Estimating the social return to higher education: evidence from longitudinal and repeated cross-sectional data. Journal of Econometrics, 121(1-2), 175-212.

O'Neill, D. (1977). Voucher funding of training programs: evidence from the GI Bill. Journal of Human Resources, 12, 425-445.

Palacios, M. (2004). Investing in human capital: a capital markets approach to higher education funding. Cambridge: Cambridge University Press.

Pissarides, C.A. (1981). Staying-on in school in England and Wales. Economica, 48, 345-363.

Pissarides, C.A. (1982). From school to university: the demand for post-compulsory education in Britain. Economic Journal, 92, 654-667.

Renkema, A. (2006). Individual learning accounts: a strategy for lifelong learning?. Den Bosch: CINOP.

Rothstein, J., \& Rouse, C. (2007). Constrained after college: student loans and early career occupational choices. NBER Working Paper No. 13117.

Turner, S., \& Bound, J. (2003). Closing the gap or widening the divide: The effects of the G.I. Bill and World War II on the educational outcomes of black Americans. Journal of Economic History, 63(1), 145-177.

World Bank (2003). Lifelong learning in the global knowledge Economy: Challenges for developing countries. Washington, DC: World Bank. 